\title{
Relationship between Selected Independent Variables and Decision Making Ability of Farm Women in Agriculture and Dairying Activities
}

\author{
Anam Khan* and R. M. Naik \\ Department of Extension Education, N.M. College of Agriculture, NAU, \\ Navsari-396450, India \\ *Corresponding author
}

Keywords

Farm women,

Decision making

ability, farm

management

Article Info

Accepted:

12 March 2021

Available Online:

10 April 2021
Women are referred to as 'invisible farmers' they are the backbone of agricultural work force in our country. A woman performs the most tedious tasks in agricultural production and they are active partners associating in almost all units of operations of agriculture. The success and failure of farm depends mainly on the contribution made by farm women. Women are involved in all important aspects related to agriculture, decision making, finance and marketing. Decision making ability is one of the important aspects which lead towards maximization of income and proper farm management. The present study was conducted in Navsari district of Gujarat in order to ascertain the relationship between selected independent variables of farm women and their decision making ability in agriculture and dairying activities. A total of 100 farm women were selected as respondents from 100 villages of all the six talukas of Navsari district.

\section{Introduction}

Farm women play a vital role within house and farm by managing all the resources effectively and efficiently. No operation in field is without them. They perform sowing, transplanting, weeding, manuring, harvesting, rearing of livestock and apart from that they are successful managers of household activities. Women as leaders, women have been an important part of social structure not only because of their continuation of human race but also by their significant contribution to the socio-economic progress and development of nation.

A farm woman as a wife and mother plays considerable role in decision making in agriculture and dairying activities. Studies on women in agriculture in India revealed that a farm woman contributes to agriculture by taking nearly 60.00 to 70.00 per cent decisions. The decision making ability of farm women certainly affect the efficiency in 
performing various operations and enhancing the production. It was felt necessary to examine the major role that farm women play in rural areas. With this objective in view it has decided to conduct an investigation entitled "Decision making ability among the farm women of Navsari district of South Gujarat', with the following specific objectives.

The main objectives of this study include to study the association between profile of farm women and decision making ability in agriculture and dairying activities

\section{Materials and Methods}

The present study carried out to find out the relationship between selected independent variables of farm women and their decision making ability in agriculture and dairying activities. Navsari district of Gujarat state was purposively selected for present study. From Navsari district all the six talukas were selected and 100 villages were selected through proportionate random sampling. Later on 100 farm women were selected randomly.

Thus sample size of 100 respondents was selected. To ascertain the relationship between selected independent variables and dependent variables, the co-efficient of correlation was worked out.

\section{Results and Discussion}

The data presented in table 1 revealed that education $(0.282 * *)$, family type $\left(0.283^{* *}\right)$, farming experience $(0.273 * *)$, land holding $(0.274 * *)$, annual income $(0.307 * *)$, mass media exposure $(0.352 * *)$, extension contact $(0.223 * *)$, social participation $(0.282 * *)$, scientific orientation $\left(0.463^{* *}\right)$, economic orientation $\left(0.277^{* *}\right)$, risk orientation $(0.304 * *)$, management orientation $(0.283 * *)$ were found positively and highly significantly associated whereas, occupation $\left(0.248^{*}\right)$ and extension contact $\left(0.223^{*}\right)$, cropping pattern $\left(0.208^{*}\right)$ are positively and significantly associated while age (0.186) is nonsignificantly associated with decision making ability among farm women in agriculture activities.

The data presented in table 2 revealed that family type $\left(0.247^{* *}\right)$, land holding $\left(0.256^{* *}\right)$, mass media exposure $\left(0.256^{* *}\right)$, extension contact $\left(0.335^{* *}\right)$, risk orientation $\left(0.282^{* *}\right)$, management orientation $(0.249 * *)$ were found positively and highly significantly associated whereas, education $\left(0.207^{*}\right)$, farming experience $\left(0.212^{*}\right)$, annual income $\left(0.215^{*}\right)$, occupation $\left(0.237^{*}\right)$, social participation $(0.201 *)$, scientific orientation $(0.227 *)$, economic orientation $\left(0.243^{*}\right)$, cropping pattern $(0.272 *)$ are positively and significantly associated while age $(-0.062)$ is non- significantly associated with decision making ability among farm women in dairying activities.

Education, family type, farming experience, land holding, annual income, mass media exposure, extension contact, social participation, scientific orientation, economic motivation, risk orientation, management orientation were found positively and highly significantly associated whereas, occupation, extension contact and cropping pattern are positively and significantly associated while age is non-significantly associated with decision making ability among farm women in agriculture activities. 
Table.1 Relationship between personal profile of farm women with their decision making ability in agriculture activities

\begin{tabular}{|c|c|c|}
\hline Sr. No. & Variables & Coefficient of correlation $(\boldsymbol{r})$ \\
\hline $\mathbf{1}$ & Age & $0.1869^{* *}$ \\
\hline $\mathbf{2}$ & Education & $0.2829^{* *}$ \\
\hline $\mathbf{3}$ & Family type & $0.2837^{* *}$ \\
\hline $\mathbf{4}$ & Farming experience & $0.2733^{* *}$ \\
\hline $\mathbf{5}$ & Land holding & $0.2748^{* *}$ \\
\hline $\mathbf{6}$ & Annual income & $0.3076^{* *}$ \\
\hline $\mathbf{7}$ & Occupation & $0.2484^{*}$ \\
\hline $\mathbf{8}$ & Mass media exposure & $0.3520^{* *}$ \\
\hline $\mathbf{9}$ & Extension contact & $0.2231^{*}$ \\
\hline $\mathbf{1 0}$ & Social participation & $0.2827^{* *}$ \\
\hline $\mathbf{1 1}$ & Scientific orientation & $0.4634^{* *}$ \\
\hline $\mathbf{1 2}$ & Economic motivation & $0.2771^{* *}$ \\
\hline $\mathbf{1 3}$ & Risk orientation & $0.3045^{* *}$ \\
\hline $\mathbf{1 4}$ & Management orientation & $0.2839^{* *}$ \\
\hline $\mathbf{1 5}$ & Cropping pattern & $0.2082^{*}$ \\
\hline
\end{tabular}

* Significant at 0.05 level** Significant at 0.01 level

Table. 2 Relationship between personal profile of farm women with their decision making ability in dairying activities

$(\mathrm{n}=100)$

\begin{tabular}{|c|c|c|}
\hline Sr. No. & Variables & Coefficient of correlation $(\boldsymbol{r})$ \\
\hline $\mathbf{1}$ & Age & -0.0629 \\
\hline $\mathbf{2}$ & Education & $0.2079^{*}$ \\
\hline $\mathbf{3}$ & Family type & $0.2475^{* *}$ \\
\hline $\mathbf{4}$ & Farming experience & $0.2123^{*}$ \\
\hline $\mathbf{5}$ & Land holding & $0.2561^{* *}$ \\
\hline $\mathbf{6}$ & Annual income & $0.2156^{*}$ \\
\hline $\mathbf{7}$ & Occupation & $0.2372^{*}$ \\
\hline $\mathbf{8}$ & Mass media exposure & $0.2568^{* *}$ \\
\hline $\mathbf{9}$ & Extension contact & $0.3356^{* *}$ \\
\hline $\mathbf{1 0}$ & Social participation & $0.2014^{*}$ \\
\hline $\mathbf{1 1}$ & Scientific orientation & $0.2273^{*}$ \\
\hline $\mathbf{1 2}$ & Economic motivation & $0.2438^{*}$ \\
\hline $\mathbf{1 3}$ & Risk orientation & $0.2821^{* *}$ \\
\hline $\mathbf{1 4}$ & Management orientation & $0.2494^{* *}$ \\
\hline $\mathbf{1 5}$ & Cropping pattern & $0.2725^{*}$ \\
\hline
\end{tabular}

* Significant at 0.05 level** Significant at 0.01 level 
Family type, land holding, mass media exposure, extension contact, risk orientation, management orientation were found positively and highly significantly associated whereas, education, farming experience, annual income, occupation, social participation, scientific orientation, economic orientation, cropping pattern are positively and significantly associated while age is negatively but non significantly associated with decision making ability among farm women in dairying activities.

\section{References}

Singh, D. K., Pramod, S., Thakur, D. S. and Anjani, K. (2015). Role of Decision
Making Process of Farm Women Regarding Vegetable Operation. Indian Journal of Extension Education. 51(3 \& 4): 62-65.

Singotiya, P., Khare, N. K. and Sonam, A.(2014). Role of tribal farm women in decision making towards agricultural operations. Advance Research Journal of Social Science. 5 (2).

Manthekar, J. S., and Nigade, D. D. (2018). Participation and Decision Making Pattern of Farm Women in Dairy Occupation. International Journal of Current Microbiology and Applied Sciences. 23(9)19.

\section{How to cite this article:}

Anam Khan and Naik, R. M. 2021. Relationship between Selected Independent Variables and Decision Making Ability of Farm Women in Agriculture and Dairying Activities. Int.J.Curr.Microbiol.App.Sci. 10(04): 347-350. doi: https://doi.org/10.20546/ijcmas.2021.1004.037 